PACS: $81.30 . \mathrm{Bx}$

\title{
DEPENDENCE OF INTERPHASE DISTRIBUTION COEFFICIENTS ON TEMPERATURE AND CONCENTRATION OF COMPONENTS IN DOUBLE METAL SYSTEMS
}

\author{
(D)Alexey P. Shcherban*, DOlga A. Datsenko \\ National Science Center "Kharkiv Institute of Physics and Technology" \\ 1, Academichna str., 61108 Kharkiv, Ukraine \\ *Corresponding Author: shcherban@kipt.kharkov.ua \\ Received May 15, 2020; accepted October 13, 2020
}

In this work the computation of the equilibrium $\mathrm{k}_{0}$ and limiting $\mathrm{k}_{0} \mathrm{limB}_{\mathrm{B}}$ distribution coefficients (DC) of the components according to the state diagrams of binary metal systems $\mathrm{Mg}-\mathrm{Ag}, \mathrm{Ag}-\mathrm{Mg}, \mathrm{Al}-\mathrm{Mg}, \mathrm{Mg}-\mathrm{Al}, \mathrm{Ni}-\mathrm{Ga}$, and $\mathrm{Nb}-\mathrm{Ge}$ was achieved. These systems belong to systems with limited solubility and for them the approximating equations of the solidus and liquidus lines are obtained in the form of second-order polynomials in the temperature range from the melting point of the main component $\mathrm{T}_{\mathrm{MA}}$ to the eutectic temperature $\mathrm{T}_{\mathrm{EA}}$. A mathematical analysis of the obtained equations for calculating $\mathrm{DC}$ is performed. For the first time by calculated and graphical methods the values of the limiting distribution coefficients kolimB for such systems as $\mathrm{Mg}-\mathrm{Al}, \mathrm{Mg}-\mathrm{Ag}$, and $\mathrm{Al}-\mathrm{Mg}$ were determined. The complete coincidence of the kolimB values obtained by different methods is confirmed. For the $\mathrm{Ag}-\mathrm{Mg}$, $\mathrm{Nb}-\mathrm{Ge}$ and $\mathrm{Ni}-\mathrm{Ga}$ systems adjusted values of the limiting coefficient were obtained, which are in good agreement with the reference values. The dependences of the equilibrium distribution coefficients on temperature and concentration for the investigated systems are constructed. In the studied temperature range from $\mathrm{T}_{\mathrm{MA}}$ to $\mathrm{T}_{\mathrm{EA}}$, a linear dependence of the distribution coefficients on temperature and concentration is observed.

KEY WORDS: equilibrium and limiting distribution coefficients, binary metal systems $\mathrm{Mg}-\mathrm{Ag}, \mathrm{Ag}-\mathrm{Mg}, \mathrm{Al}-\mathrm{Mg}, \mathrm{Mg}-\mathrm{Al}, \mathrm{Ni}-\mathrm{Ga}$, $\mathrm{Nb}-\mathrm{Ge}$

Crystallization from melt is an important process that most materials undergo during their manufacture, refining, and shaping. Directional crystallization is especially significant in the production of ultrapure materials, primarily in semiconductor technology. The most important parameter of the crystallization process for the targeted use of its refining action and the formation of solid solutions is the interphase distribution coefficient (DC).

The distribution coefficient characterizes the ratio of the concentration of components in various phases in thermodynamic equilibrium. By their physicochemical definition, DC differ for each concrete pair of a base component. In this work, the distribution coefficient is used only to describe the concentration ratio at the liquid - solid interphase equilibrium, in this case it is determined by the concentration ratio in the solid and liquid phases. The general expression for equilibrium DC has the form of dependence: $k_{0}=x_{S} / x_{L}$. In the following considerations, the existence of binary metal systems consisting of two components A - B is assumed.

The following distribution coefficients are considered in the literature [1-4]: effective DC $\mathrm{k}_{\mathrm{B}}$, equilibrium DC $\mathrm{k}_{0 \mathrm{~B}}$ and limiting DC $\mathrm{k}_{0 \mathrm{limB}}$. There are various both experimental and computational methods for determining the distribution coefficients. In turn, the choice of the determination method of DC depends on the nature of the solubility of the second component in the base: low solubility, limited and unlimited solubility. In [3], an analysis was made of the methods for determining distribution coefficients depending on the type of solubility of the second component in the base.

\section{FORMULATION OF THE PROBLEM}

The effective distribution coefficient $\mathrm{k}_{\mathrm{B}}$ during directional crystallization is the ratio of the impurity concentration in the initial and final part of the ingot (zone melting, the Bridgman method), or the ratio of the impurity concentration in the ingot and the residue in the crucible (Czochralsky method). The $\mathrm{k}_{\mathrm{B}}$ coefficient varies over a wide range from values less than $1 \cdot 10^{-3}$ to values greater than 10 , which depends on the solidification conditions - crystallization rate and degree of mixing of the liquid. The $\mathrm{k}_{\mathrm{B}}$ values determined in different experimental methods and conditions of directional crystallization cannot be compared with each other and cannot be operated on to construct any dependencies, correlations, etc. The $\mathrm{k}_{\mathrm{B}}$ values can be used only for a rough estimate of the behavior of the components during crystallization. The $\mathrm{k}_{\mathrm{B}}$ experimental values for a wide range of binary systems are given in [1].

The limiting distribution coefficient $\mathrm{k}_{0 \text { limB }}$ is based on the value of the equilibrium distribution coefficient $\mathrm{k}_{0 \mathrm{~B}}$ upon extrapolation of the content of the second component to zero concentration. The calculation methods for determining $\mathrm{k}_{0 \text { limB }}$ depend on the type of solubility of the impurity in the base and are described in [3, 5, 6]. In these works, the calculated values of the limiting distribution coefficient are given for many systems with different solubilities of the components in the solid state. The temperature and concentration parameters were established there to achieve the limiting values of $\mathrm{k}_{01 \mathrm{imB}}: \mathrm{x}_{\mathrm{LB}}<0.1$ at. $\%$ and $\Delta \mathrm{T}_{\mathrm{MA}}<1 \mathrm{~K}$. Below the specified parameters $\mathrm{k}_{0 l i m B}$ is defined uniquely and assumes its constant value.

The equilibrium distribution coefficient of the impurity $\mathrm{k}_{0 \mathrm{~B}}$ is equal to the ratio of the equilibrium concentrations of this component in two adjacent phases, and not concentrations in general. Although in practice, equilibrium (C) A.P. Shcherban, O.A. Datsenko, 2020 
solidification is rarely achieved, because the rate of diffusion in the solid state is usually low; to estimate the distribution of the second component during crystallization of a substance from a melt, it is precisely the $\mathrm{k}_{0 \mathrm{~B}}$ equilibrium DC that have the main practical value as a reference material.

In the reference literature, experimental and calculated values of $\mathrm{k}_{0 \mathrm{~B}}$ are given $[1,6]$. As a rule, these values are given for one concentration value of the second component, or even without indicating concentration. The equilibrium distribution coefficient $\mathrm{k}_{0 \mathrm{~B}}$, by definition, characterizes the ratio between the concentrations of components in two phases that are in equilibrium with each other under isothermal conditions. Based on the binary state diagram, the dependence of this coefficient on temperature and concentration is determined in general terms by the formula:

$$
k_{0 B}(\mathrm{~T}, \mathrm{x})=\mathrm{f}\left(\mathrm{x}_{\mathrm{SB}}(\mathrm{T}) / \mathrm{x}_{\mathrm{LB}}(\mathrm{T})\right) .
$$

Thus, the distribution coefficient can be considered as a function of temperature and concentration. If the liquidus and solidus lines of the state diagram (SD) are known with sufficient accuracy, then it is possible to determine the dependence of the equilibrium distribution coefficient functions on temperature and concentration for a fragment of the $\mathrm{SD}$, for example, on the melting point of the main component to the singular points on the diagram (minimum point , maximum, eutectics, etc.). The literature data of the dependence of the equilibrium distribution coefficient $\mathrm{k}_{0 \mathrm{~B}}$ on temperature and concentration for binary metal are very limited, therefore, research in this direction is of interest.

The aim of the work is to study the dependence of equilibrium distribution coefficients on temperature and concentration for individual metal systems with limited solubility of components in the solid $\alpha$-phase.

\section{CALCULATION METHOD}

In this work, we studied the following binary metal systems: $\mathrm{Mg}-\mathrm{Ag}, \mathrm{Ag}-\mathrm{Mg}, \mathrm{Al}-\mathrm{Mg}, \mathrm{Mg}-\mathrm{Al}, \mathrm{Ni}-\mathrm{Ga}$, and $\mathrm{Nb}-\mathrm{Ge}$. The choice of these systems is due to the fact that they relate to systems with limited solubility and they were investigated for calculating such thermodynamic quantities as the partial dissolution enthalpy $\Delta \bar{H}_{B}^{\alpha}$, activity coefficients $\gamma_{B}^{\alpha}$, and component activity $a_{B}^{\alpha}$ in these systems [7].

An analysis of the state diagrams of the explored systems [8] showed that their solidus and liquidus lines in the temperature range from the melting point of the pure component to the eutectic temperature are not linear and therefore $\mathrm{k}_{0 \mathrm{~B}}$ is a function of temperature and concentration in this interval according to expression (1).

To calculate the dependence of the equilibrium $\mathrm{DC} \mathrm{k}_{0 \mathrm{~B}}$ on temperature and concentration, we used the method for determining the equilibrium distribution coefficients from binary state diagrams described in [6,9]. This method consists in the mathematical expression of the shape of the solidus and liquidus lines of state diagrams in the form of second-order polynomials:

$$
\begin{aligned}
& T_{S}=p_{S B} x_{S B}^{* 2}+q_{S B} x_{S B}^{*}+T_{M A} \\
& T_{L}=p_{L B} x_{L B}^{* 2}+q_{S L} x_{L B}^{*}+T_{M A},
\end{aligned}
$$

where $T_{S}$ and $T_{L}$ - solidus and liquidus temperatures, $T_{M A}-$ melting point of the main component $\mathrm{A}, x_{S B}^{*}, x_{L B}^{*}-$ molar fractions of component B in the solid and liquid phase, expressed in at. $\%, p_{S B}, q_{S B}, p_{L B}, q_{L B}$ - regression coefficients of approximating equations.

Since equilibrium DC is an isothermal concentration ratio $x_{S}^{*} / x_{L}^{*}$, equality have been observed

$$
\Delta T_{S}=\Delta T_{L}=T_{M A}-T_{S}=T_{M A}-T_{L}=\Delta T_{M A} .
$$

Considering condition (4), from expressions (1) and (2), it is possible write the equality:

$$
p_{S B} x_{S B}^{* 2}+q_{S B} x_{S B}^{*}=p_{L B} x_{L B}^{* 2}+q_{L B} x_{L B}^{*} .
$$

From this expression it is possible to derive the obvious expression $\mathrm{k}_{0 \mathrm{~B}}$ as a function of the impurity concentration:

$$
k_{0 B}^{C}=\left(p_{L B} x_{L B}^{*}+q_{L B}\right) /\left(p_{S B} x_{S B}^{*}+q_{S B}\right) .
$$

In the same way, excluding concentration, it is possible to obtain an expression for the temperature dependence of the equilibrium distribution coefficient: 


$$
k_{0 B}^{T}=\frac{p_{L B}\left( \pm \sqrt{q_{S B}^{2}-4 p_{S B} \Delta T_{M A}}-q_{S B}\right)}{p_{S B}\left( \pm \sqrt{q_{L B}^{2}-4 p_{L B}} \Delta T_{M A}-q_{L B}\right)} .
$$

The degree of temperature influence is determined by the specific properties of the considered pair of substances. The regression coefficients $p_{S B}, p_{L B}, q_{S B}, q_{L B}$ were determined by the least squares method using the pairs of values taken from the state diagrams: $\mathrm{T}_{\mathrm{S}(\mathrm{i})}, \mathrm{x}_{\mathrm{SB}(\mathrm{i})}$ and $\mathrm{T}_{\mathrm{L}(\mathrm{j})}, \mathrm{x}_{\mathrm{LB}(\mathrm{j})}$. It should be noted the scope of the regression equations (2) and (3). Their application is limited in the range from the melting temperature of the $\mathrm{T}_{\mathrm{MA}}$ of the main component to the maximum temperature equal to the eutectic temperature $\mathrm{T}_{\max }=\mathrm{T}_{\mathrm{EA}}$.

As noted above, the limiting distribution coefficient $\mathrm{k}_{0 \text { limB }}$ is determined by extrapolating the content of the second component to zero concentration $\mathrm{x}_{\mathrm{B}} \rightarrow 0$ or at $\mathrm{T} \rightarrow \mathrm{T}_{\mathrm{MA}}$. This value can be obtained from formula (6) for $\mathrm{x}_{\mathrm{LB}}^{*}=x_{S B}^{*}=0$.

$$
k_{0 \lim B}=q_{L B} / q_{S B} .
$$

Table 1 shows the values of the regression coefficients of the approximating equations of the solidus and liquidus lines of the investigated systems and the temperature range of applicability of the equations, as well as the first calculated values of the limiting distribution coefficients $\mathrm{k}_{0 l i m B}$ for such systems as $\mathrm{Mg}-\mathrm{Al}, \mathrm{Mg}-\mathrm{Ag}, \mathrm{Al}-\mathrm{Mg}$. For the $\mathrm{Ag}-\mathrm{Mg}, \mathrm{Nb}-\mathrm{Ge}$, and $\mathrm{Ni}-\mathrm{Ga}$ systems, the refined values of the limiting coefficient were obtained, which are in good agreement with the reference values [6].

Table 1.

The values of the regression coefficients of the equations of the solidus and liquidus lines in the AB investigated systems, the temperature range of the equations applicability and $\mathrm{k}_{0 \mathrm{limB}}$ values

\begin{tabular}{|c|c|c|c|c|c|c|c|}
\hline System & $\mathrm{p}_{\mathrm{S}}$ & $\mathrm{qS}_{\mathrm{S}}$ & $\mathrm{p}_{\mathrm{L}}$ & $\mathrm{q}_{\mathrm{L}}$ & $\Delta \mathrm{T}_{\mathrm{MA}},{ }^{\circ} \mathrm{C}$ & KolimB & $\kappa_{\text {OllimB }}[6]$ \\
\hline $\mathrm{Ag}-\mathrm{Mg}$ & 0,0394 & $-8,3938$ & $-0,0458$ & $-4,6347$ & 202 & 0,55 & 0,56 \\
\hline $\mathrm{Mg}-\mathrm{Ag}$ & 13,8307 & $-92,5442$ & $-0,2139$ & $-6,5556$ & 178 & 0,07 & - \\
\hline $\mathrm{Mg}-\mathrm{Al}$ & 0,0799 & $-18,8156$ & $-0,0917$ & $-4,2488$ & 212 & 0,23 & - \\
\hline $\mathrm{Al}-\mathrm{Mg}$ & 0,3810 & $-17,8458$ & $-0,0210$ & $-4,7629$ & 210 & 0,27 & - \\
\hline $\mathrm{Nb}-\mathrm{Ge}$ & 3,7895 & $-89,9375$ & $-0,4615$ & $-15,4285$ & 569 & 0,17 & 0,3 \\
\hline $\mathrm{Ni}-\mathrm{Ga}$ & 0,2098 & $-15,9277$ & $-0,1198$ & $-4,2990$ & 243 & 0,27 & 0,4 \\
\hline
\end{tabular}

Figure 1 shows the dependences of the equilibrium distribution coefficients $k_{0 B}^{T}$ depending on the $\Delta \mathrm{T}_{\mathrm{MA}}$ constructed by expression (7) for $\mathrm{Ag}-\mathrm{Mg}, \mathrm{Ni}-\mathrm{Ga}, \mathrm{Al}-\mathrm{Mg}, \mathrm{Mg}-\mathrm{Al}, \mathrm{Nb}-\mathrm{Ge}, \mathrm{Mg}-\mathrm{Ag}$ systems.

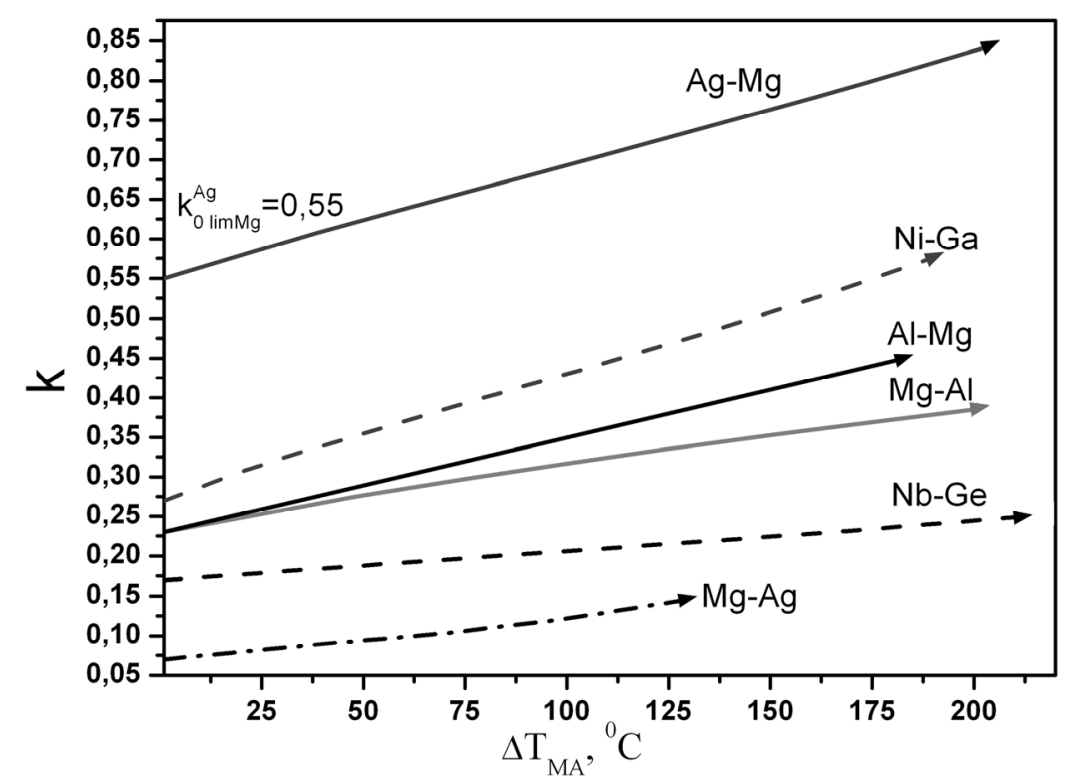

Figure 1. Dependences of equilibrium distribution coefficients on $\Delta \mathrm{T}_{\mathrm{MA}}$ for systems $\mathrm{Ag}-\mathrm{Mg}$, Ni-Ga, $\mathrm{Al}-\mathrm{Mg}, \mathrm{Mg}-\mathrm{Al}, \mathrm{Nb}-\mathrm{Ge}, \mathrm{Mg}-\mathrm{Ag}$.

An analysis of the obtained dependences shows that for the investigated systems, a linear dependence $k_{0 B}^{T}$ from $\Delta \mathrm{T}_{\mathrm{MA}}$ is observed in the temperature range from the melting point of the main component $\mathrm{T}_{\mathrm{MA}}$ to the eutectic temperature $\mathrm{T}_{\mathrm{EA}}$. 
The nature of the concentration, as well as temperature, dependence of the equilibrium distribution coefficient is determined by the topology of the phase diagram drawing: the mutual disposition of the liquidus and solidus lines. To determine the concentration dependence of equilibrium DC $k_{0 B}^{C}$, expression (6) is used. Table 2 shows the calculated values $k_{0 B}^{C}$ and $k_{0 B}^{T}$ in the investigated systems obtained from expressions (6) and (7) for the same $\Delta \mathrm{T}_{\mathrm{MA}}$ values. As can be seen from the table, either a complete coincidence of the obtained values is observed, or a slight deviation $(<1 \%)$

Table 2

The calculated values of distribution coefficients $k_{0 B}^{C}, k_{0 B}^{T}$ obtained for the same values $\Delta \mathrm{T}_{\mathrm{MA}}$

\begin{tabular}{|c|c|c|c|c|c|c|c|c|}
\hline \multicolumn{3}{|c|}{$\mathrm{Ag}-\mathrm{Mg}$} & \multicolumn{3}{c|}{$\mathrm{Nb}-\mathrm{Ge}$} & \multicolumn{3}{c|}{$\mathrm{Mg}-\mathrm{Al}$} \\
\hline$k_{0 B}^{C}$ & $k_{0 B}^{T}$ & $\Delta \mathrm{T}_{\mathrm{MA}}$ & $k_{0 B}^{C}$ & $k_{0 B}^{T}$ & $\Delta \mathrm{T}_{\mathrm{MA}}$ & $k_{0 B}^{C}$ & $k_{0 B}^{T}$ & $\Delta \mathrm{T}_{\mathrm{MA}}$ \\
\hline 0.61 & 0.608 & 38.93 & 0.203 & 0.207 & 90.756 & 0.252 & 0.252 & 23.97 \\
\hline 0.635 & 0.635 & 57.93 & 0.231 & 0.236 & 168.55 & 0.275 & 0.275 & 48 \\
\hline 0.662 & 0.664 & 78.93 & 0.231 & 0.236 & 168.55 & 0.298 & 0.298 & 75.7 \\
\hline 0.703 & 0.703 & 106.93 & 0.269 & 0.269 & 248.93 & 0.353 & 0.353 & 150.16 \\
\hline 0.748 & 0.745 & 136.93 & 0.299 & 0.298 & 313.756 & 0.386 & 0.385 & 200 \\
\hline \multicolumn{7}{|c|}{$\mathrm{Mg}-\mathrm{Ag}$} \\
\hline$k_{0 B}^{C}$ & $k_{0 B}^{T}$ & $\Delta \mathrm{T}_{\mathrm{MA}}$ & $k_{0 B}^{C}$ & $k_{0 B}^{T}$ & $\Delta \mathrm{T}_{\mathrm{MA}}$ & $k_{0 B}^{C}$ & $k_{0 B}^{T}$ & $\Delta \mathrm{T}_{\mathrm{MA}}$ \\
\hline 0.089 & 0.09 & 41 & 0,29 & 0.293 & 42.322 & 0.306 & 0.306 & 19.776 \\
\hline 0.103 & 0.104 & 71 & 0,302 & 0.304 & 58.822 & 0.393 & 0.393 & 75 \\
\hline 0.12 & 0.121 & 99 & 0.345 & 0.345 & 109.572 & 0.482 & 0.482 & 134.27 \\
\hline 0.146 & 0.145 & 129 & 0.364 & 0.364 & 127.452 & 0.532 & 0.531 & 164.45 \\
\hline 0.195 & 0.21 & 157 & 0.384 & 0.387 & 146.452 & 0.573 & 0.573 & 188.388 \\
\hline
\end{tabular}

From the obtained coinciding values $k_{0 B}^{T}$ and $k_{0 B}^{C}$ for the same $\Delta \mathrm{T}_{\mathrm{MA}}$ values (table 1), it is possible to conclude that the concentration dependence of the distribution coefficients will have, as well as the temperature, a linear dependence.

From the expressions (2) and (3) it follows that the distribution coefficient can be represented as:

$$
\begin{aligned}
& k_{0 B}^{A}=f\left(x_{L}\right) ; \\
& k_{0 B}^{A}=f\left(x_{S}\right) .
\end{aligned}
$$

The extrapolation of these functions as $\mathrm{x}_{\mathrm{B}} \rightarrow 0$ allows us to determine the value of the limiting coefficient. Figure 2 shows the dependence curves $k_{0 B}^{A}=f\left(x_{L}, x_{B}\right)$ for the binary systems studied in this work. To build the concentration dependences, atomic percentages (at.\%) of the components concentrations of the corresponding lines of liquidus and solidus were used.
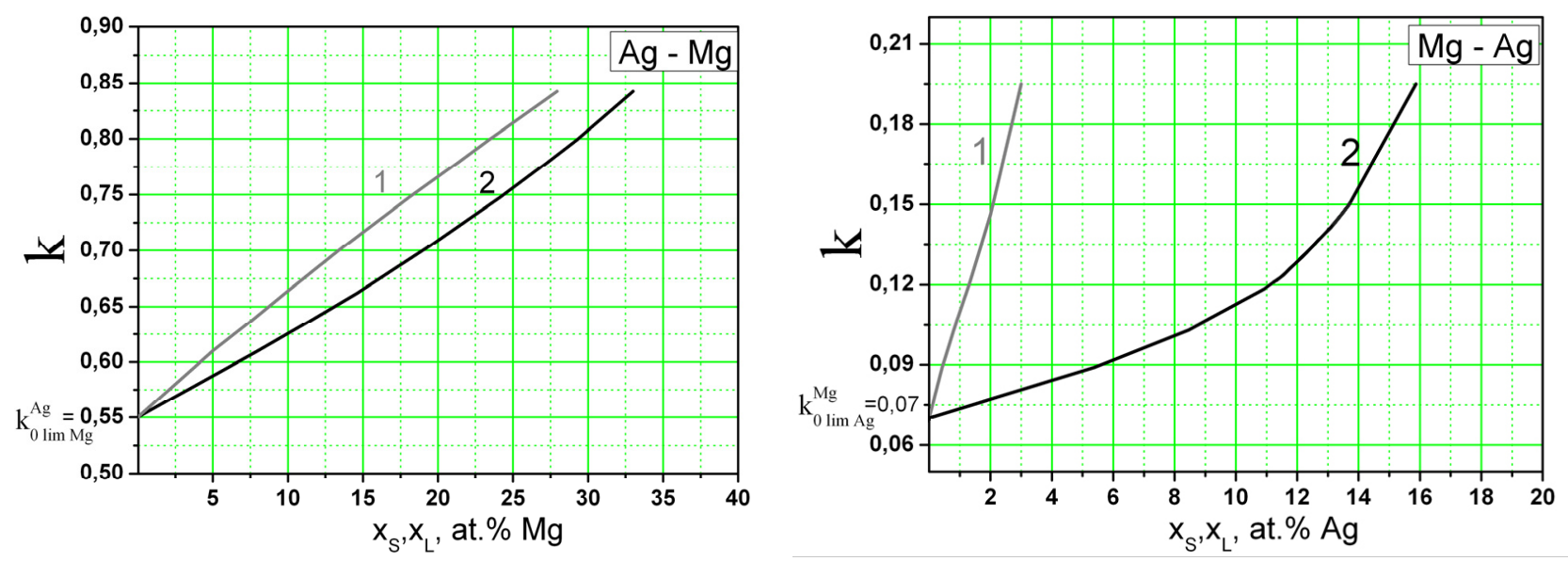

Figure 2. Dependences of equilibrium coefficients on the concentration of the second component in solid $k_{0 B}^{A}=f\left(x_{S}\right)-1$ and liquid $k_{0 B}^{A}=f\left(x_{\mathrm{L}}\right)-2$ phases for binary systems $\mathrm{Mg}-\mathrm{Ag}, \mathrm{Ag}-\mathrm{Mg}, \mathrm{Al}-\mathrm{Mg}, \mathrm{Mg}-\mathrm{Al}, \mathrm{Ni}-\mathrm{Ga}, \mathrm{Nb}-\mathrm{Ge}$.

(Continued on next page) 

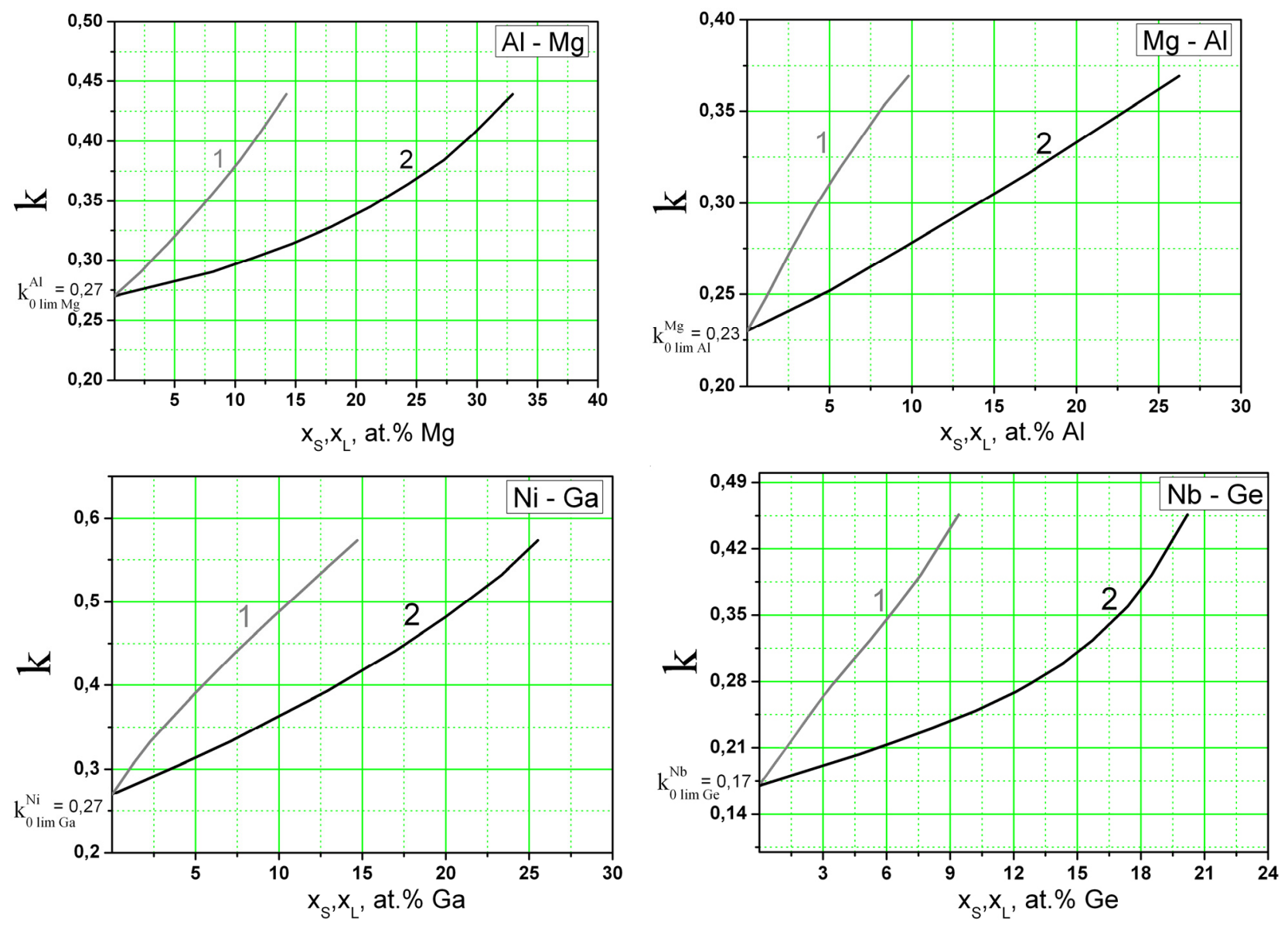

Figure 2. Dependences of equilibrium coefficients on the concentration of the second component in solid $k_{0 B}^{A}=f\left(x_{S}\right)-1$ and liquid

$$
k_{0 B}^{A}=f\left(x_{\mathrm{L}}\right)-2 \text { phases for binary systems } \mathrm{Mg}-\mathrm{Ag}, \mathrm{Ag}-\mathrm{Mg}, \mathrm{Al}-\mathrm{Mg}, \mathrm{Mg}-\mathrm{Al}, \mathrm{Ni}-\mathrm{Ga}, \mathrm{Nb}-\mathrm{Ge} .
$$

The curves have a different character depending on the curvature of the solidus and liquidus lines. However, they have a common intersection point as $\mathrm{B} \rightarrow 0$, which characterizes the limiting value $k_{0 \lim B}^{A}$. The above calculations can be considered an additional graphical method for determining the limiting DC, and (or) use it to refine and verify the values of the limiting coefficients obtained by other methods.

\section{CONCLUSIONS}

By approximating the solidus and liquidus lines of the state diagrams in the form of second-order equations, the parameters for determining the equilibrium distribution coefficients in the $\mathrm{Mg}-\mathrm{Ag}, \mathrm{Ag}-\mathrm{Mg}, \mathrm{Al}-\mathrm{Mg}, \mathrm{Mg}-\mathrm{Al}, \mathrm{Ni}-$ $\mathrm{Ga}, \mathrm{Nb}-\mathrm{Ge}$ systems depending on the interfacial temperature equilibrium $k_{0 B}^{T}$ and concentration of components $k_{0 B}^{C}$ are obtained.

The dependences of the equilibrium distribution coefficients on temperature $k_{0 B}^{T}$ and concentration $k_{0 B}^{C}$ for the investigated systems are constructed. In the temperature range from the melting point of the main component of $\mathrm{T}_{\mathrm{MA}}$ to the temperature of the eutectic $\mathrm{T}_{\mathrm{EA}}$, a linear dependence of $k_{0 B}^{T}$ and $k_{0 B}^{C}$ are observed.

By method of the analysis of binary state diagrams, the limiting distribution coefficients $\mathrm{k}_{0 \text { limB }}$ for such systems as $\mathrm{Mg}-\mathrm{Al}, \mathrm{Mg}-\mathrm{Ag}$, and $\mathrm{Al}-\mathrm{Mg}$ were first determined. For the $\mathrm{Ag}-\mathrm{Mg}, \mathrm{Nb}-\mathrm{Ge}$, and $\mathrm{Ni}-\mathrm{Ga}$ systems, refined values of the limiting coefficient were obtained, which are in good agreement with the reference values.

Based on the constructed dependences, the limiting distribution coefficients $\mathrm{k}_{0 l i m B}$ were obtained for the $\mathrm{Mg}-\mathrm{Ag}$, $\mathrm{Ag}-\mathrm{Mg}, \mathrm{Al}-\mathrm{Mg}, \mathrm{Mg}-\mathrm{Al}, \mathrm{Ni}-\mathrm{Ga}, \mathrm{Nb}-\mathrm{Ge}$ systems, whose values coincide with the calculated values.

\section{ORCID IDs}

(D)Alexey P. Shcherban, https://orcid.org/0000-0002-6004-0579; (DOlga A. Datsenko, https://orcid.org/0000-0002-5512-9878

\section{REFERENCES}

[1] L.A. Niselson, and A.G. Yaroshevsky, Межфазные коэффициенты распределения [Interphase distribution coefficients], (Nauka, Moscow, 1992), pp. 399. (in Russian) 
[2] V. Phfann, Зонная плавка [Zone melting], (Metallurgizdat, Moscow, 1960), pp. 366. (in Russian)

[3] A.P. Scherban, Journal of V.N. Karazin Kharkiv National University. Series Nuclei, particles, fields, 946(1), 75-80 (2011), http://nuclear.univer.kharkov.ua/lib/946_1(49)_11_p75-80.pdf. (in Russian)

[4] G.P. Kovtun, A.P. Shcherban, and O.A. Datsenko, Коэффициенты распределения примесей в кадмии, иинке и теллуре при кристаллизационной очистке [The distribution coefficients of impurities in cadmium, zinc and tellurium during crystallization treatment], Preprint, NSC KIPT, Kharkov, 2006), pp. 32. (in Russian)

[5] G.P. Kovtun, A.P. Scherban, and O.A. Datsenko, Problems of Atomic Science and Technology, Series "Vacuum, Pure Materials, Superconductors", 5(13), 3-6 (2003). (in Russian)

[6] I. Barthel, E. Buring, K. Hein, and L. Kuharzh, Кристаллизачия из расплавов [Crystallization from melts], Ref. ed. Translation from German, (Metallurgy, Moscow, 1987), pp. 320. (in Russian)

[7] A.P. Shcherban, and O.A. Datsenko, Problems of Atomic Science and Technology, Series "Vacuum, Pure Materials, Superconductors", 1(125), 21-26 (2020).

[8] N.P. Lyakishev, Диаграмлы сосотояния T.1 [Phase diagrams Vol. 1], (Mashinostroyeniye, Moscow, 1996), pp. 991; N.P. Lyakishev, Диаграммы сосотояния T.2 [Phase diagrams Vol. 2], (Mashinostroyeniye, Moscow, 1997), pp.1023; N.P. Lyakishev, Диаграммы сосотояния T.3 [Phase diagrams Vol. 3], (Mashinostroyeniye, Moscow, 2001), pp. 872. (in Russian)

[9] L. Kuchař, B. Wozniaková, and J. Drápala, Segregation behavior during the zone melting of refractory metals, Journal of Crystal Growth, 52, 359-366 (1981), https://doi.org/10.1016/0022-0248(81)90219-0.

\section{ЗАЛЕЖНІСТЬ МІЖФАЗНИХ КОЕФІЦІЕНТІВ РОЗПОДІЛУ ВІД ТЕМПЕРАТУРИ І КОНЦЕНТРАЦІЇ КОМПОНЕНТІВ У ПОДВІЙНИХ МЕТАЛЕВИХ СИСТЕМАХ \\ О.П. Щербань, О.А. Даценко}

Національний науковий центр Харківський фізико-технічний інститут

вул. Академічна, 1, 61108, Харків, Украӥна

В роботі виконано розрахунок рівноважних $\mathrm{k}_{0}$ і граничних $\mathrm{k}_{0 \mathrm{limB}}$ коефіцієнтів розподілення (КР) компонентів по діаграмах стану подвійних металевих систем $\mathrm{Mg}-\mathrm{Ag}$, Ag-Mg, Al-Mg, Mg-Al, Ni-Ga, Nb-Ge. Ці системи відносяться до систем 3 обмеженою розчинністю і для них отримані апроксимуючі рівняння ліній солідуса і ліквідусу у вигляді поліномів другого порядку в інтервалі температур від точки плавлення основного компонента ТмА до температури евтектики ТЕА. Виконано математичний аналіз отриманих рівнянь для розрахунків КР. Розрахунковим і графічним методами вперше визначено значення граничних коефіцієнтів розподілу k0limв для таких систем як $\mathrm{Mg}-\mathrm{Al}, \mathrm{Mg}-\mathrm{Ag}$, Al-Mg. Підтверджено повний збіг значень kolimB, отриманих різними методами. Для систем $\mathrm{Ag}-\mathrm{Mg}$, Nb-Ge, Ni-Ga отримані уточнені величини граничних коефіцієнтом, які добре збігаються з довідковими значеннями. Побудовано залежності рівноважних коефіцієнтів розподілу від температури і концентрації для досліджуваних систем. У досліджуваному інтервалі температур від $\mathrm{T}_{\mathrm{MA}}$ до ТЕА спостерігається лінійна залежність коефіцієнтів розподілу від температури і концентрації.

КЛЮЧОВІ СЛОВА: рівноважні і граничні коефіцієнти розподілу, подвійні металеві системи, $\mathrm{Mg}-\mathrm{Ag}, \mathrm{Ag}-\mathrm{Mg}, \mathrm{Al}-\mathrm{Mg}$, $\mathrm{Mg}-\mathrm{Al}, \mathrm{Ni}-\mathrm{Ga}, \mathrm{Nb}-\mathrm{Ge}$

\section{ЗАВИСИМОСТЬ МЕЖФАЗНЫХ КОЭФФИЦИЕНТОВ РАСПРЕДЕЛЕНИЯ ОТ ТЕМПЕРАТУРЫ И КОНЦЕНТРАЦИИ КОМПОНЕНТОВ В ДВОЙНЫХ МЕТАЛЛИЧЕСКИХ СИСТЕМАХ А.П. Щербань, О.А. Даценко \\ Национальный Научный Центр Харьковский физико-технический институт ул. Академическая, 1, 61108, Харьков, Украина}

В работе выполнен расчет равновесных $\mathrm{k}_{0}$ и предельных $\mathrm{k}_{0} \mathrm{limB}$ коэффициентов распределения (КР) компонентов по диаграммам состояния двойных металлических систем $\mathrm{Mg}-\mathrm{Ag}, \mathrm{Ag}-\mathrm{Mg}$, $\mathrm{Al}-\mathrm{Mg}, \mathrm{Mg}-\mathrm{Al}, \mathrm{Ni}-\mathrm{Ga}, \mathrm{Nb}-\mathrm{Ge}$. Эти системы относятся к системам с ограниченной растворимостью и для них были получены аппроксимирующие уравнения линий солидуса и ликвидуса в виде полиномов второго порядка в интервале температур от точки плавления основного компонента $\mathrm{T}_{\mathrm{MA}}$ до температуры эвтектики ТЕА. Выполнен математический анализ полученных уравнений для расчетов КР. Расчетным и графическим методами впервые определены значения предельных коэффициентов распределения k0limB для таких систем как $\mathrm{Mg}-\mathrm{Al}, \mathrm{Mg}-\mathrm{Ag}, \mathrm{Al}-\mathrm{Mg}$. Подтверждено полное совпадение значений kolimB, полученных разными методами. Для систем $\mathrm{Ag}-\mathrm{Mg}, \mathrm{Nb}-\mathrm{Ge}, \mathrm{Ni}-\mathrm{Ga}$ получены уточненные величины предельных коэффициентом, которые хорошо совпадают со справочными значениями. Построены зависимости равновесных коэффициентов распределения от температуры и концентрации для исследуемых систем. В исследуемом интервале температур от ТМА до ТЕА наблюдается линейная зависимость коэффициентов распределения от температуры и концентрации.

КЛЮЧЕВЫЕ СЛОВА: равновесные и предельные коэффициенты распределения, двойные металлические системы, $\mathrm{Mg}-\mathrm{Ag}, \mathrm{Ag}-\mathrm{Mg}, \mathrm{Al}-\mathrm{Mg}, \mathrm{Mg}-\mathrm{Al}, \mathrm{Ni}-\mathrm{Ga}, \mathrm{Nb}-\mathrm{Ge}$ 